\title{
KAJIAN ADOPSI TEKNOLOGI UNTUK MENINGKATKAN DAYA SAING INDUSTRI PANGAN SKALA KECIL DI SUMATERA BARAT
}

\author{
Gunarif Taib $_{1}$, Asmawi², dan Novi Elian² \\ ${ }^{1}$ Fakultas Teknologi Pertanian Universitas Andalas \\ ${ }^{2}$ Fakultas Ilmu Sosial dan Politik Universitas Andalas \\ Email: gunariftaib@yahoo.com
}

\begin{abstract}
ABSTRAK
Industri pangan skala kecil sangat berperan dalam peningkatan ekonomi kerakyatan. Karena itu pengembangannya harus diupayakan semaksimal mungkin. Salah satu upaya yang harus dilaksanakan adalah meningkatkan teknologinya. Upaya ini dilakukan dengan melakukan pelatihan, akan tetapi hasilnya belum optimal. Hal ini disebabkan karena adopsi teknologi hasil pelatihan tidak terlaksana dengan baik. Untuk itu perlu dikaji sampai seberapa jauh pemilik industri pangan skala kecil mampu melakukan adopsi teknologi. Penelitian ini dilaksanakan untuk mengetahui permasalahan adopsi teknologi tersebut. Data primer diperoleh melalui wawancara secara mendalam dengan pemilik industri pangan skala kecil di beberapa sentra industri pangan skala kecil di Sumatera Barat. Dari penelitian ini diketahui bahwa adopsi teknologi membutuhkan pendampingan usaha pasca pelatihan dan materi pelatihan harus sesuai dengan kebutuhan industri pangan lokal. Pemilik industri membutuhkan materi pelatihan yang mampu meningkatkan mutu produk sehingga bisa meningkatkan penjualan. Dampak teknologi ditentukan oleh mutu produk yang dihasilkan, jumlah produksi, peningkatan keuntungan dan peningkatan pemasaran.

Kata kunci-adopsi, industri, pangan, teknologi
\end{abstract}

\section{PENDAHULUAN}

Pengembangan industri pangan skala kecil dimaksudkan untuk meningkatkan nilai tambah produk pertanian. Akan tetapi, sampai saat ini industri kecil ini belum berkembang dengan baik karena masih mempunyai permasalahan pada pengadaan bahan baku, mutu produk dan pemasaran (Taib, 2014). Untuk menghadapi persaingan pasar yang semakin kompetitif, khususnya dalam era Perdagangan Bebas Asean (Masyarakat Ekonomi Asean), maka semua masalah ini harus diperhatikan dengan serius.

Di Sumatera Barat, usaha skala kecil mendominasi perkembangan industri. Pada tahun 2014 industri skala kecil jumlahnya 93,4 persen dan skala menengah besar 6,6 persen (Dinas Koperasi dan Perdagangan Sumbar, 2015). Sesuai dengan kebijakan nasional, maka pengembangan industri pangan skala kecil diarahkan pada hal berikut ini: (a) kluster industri pangan yang terintegrasi dengan sentra produksi bahan baku serta sarana penunjang lainnya, (b) kemitraan industri dengan industri skala besar, (c) penetapan regulasi pada industri pangan skala besar (d) peningkatan daya saing yang tinggi. Sebagai acuan dalam pengembangan industri kecil, pemerintah telah menetapkan Road Map pengembangan industri (Departemen Perindustrian RI, 2009). Sesuai dengan panduan yang ada, maka Pemerintah Provinsi Sumatera Barat membentuk kelompok usaha yang tergabung dalam "Unit Pelayanan dan Pengembangan Pengolahan Hasil Pertanian". Kelompok usaha ini merupakan embrio dari klaster industri pangan skala kecil di Sumatera Barat. Sampai tahun 2014, telah terbentuk 126 kelompok usaha pangan skala kecil yang tersebar di seluruh Kabupaten/Kota di Sumatera Barat (Dinas Pertanian Sumatera Barat, 2015).

Salah satu kelemahan industri pangan skala kecil adalah rendahnya penguasaan teknologi pengolahan. Berbagai pelatihan telah dilaksanaan oleh berbagai intitusi pemerintah, namun demikian adopsi teknologinya masih rendah (Taib, 2015). Untuk itu diperlukan usaha nyata guna memastikan terlaksananya adopsi teknologi oleh industri kecil ini. Bargal (2009) menyatakan bahwa pemerintah harus memberikan dukungan pada industri karena memberikan dampak positif bagi perkembangan industri secara keseluruhan. Untuk itu institusi pemerintah yang terkait dengan industri harus berperan secara aktif. Dukungan bisa diberikan dalam bentuk pelatihan untuk trasnformasi teknologi, karena teknologi sangat dibutuhkan untuk peningkatan mutu produk dan efisiensi produksi. Saikia (2012) menyatakan bahwa industri skala kecil sebaiknya menerapkan teknologi padat karya, namun 
penerapan teknologi harus mempertimbangkan aspek finansial pada usaha tersebut. Kombinasi teknologi yang tepat dan kemampuan dana yang baik akan mempercepat usaha kecil berkembang dengan baik.

Devanath (2008) menyatakan bahwa perkembangan dunia usaha termasuk usaha skala kecil sangat dipengaruhi oleh inovasi teknologi. Khusus usaha skala kecil sangat perlu mempunyai spesifikasi dalam berproduksi serta memilih teknologi yang tepat untuk dikembangkan dalam usahanya. Dengan mengadopsi teknologi yang tepat guna maka industri kecil akan mampu menghasilkan produk yang bermutu. Selain itu, teknologi tepat guna lebih mudah dalam operasional dan perawatan alatnya.

\section{METODOLOGI PENELITIAN}

\section{A. Lokasi dan Waktu}

Penelitian dilakukan di Kabupaten Agam, Kabupaten 50 Kota, Kabupaten Solok dan Kota Pariaman. Keempat lokasi ini dipilih karena merupakan sentra produksi pangan olahan skala kecil di Sumatera Barat.

\section{B. Prosedur Percobaan}

Penelitian ini menggunakan desain penelitian studi kasus observasi. Dengan teknik observasi pada studi kasus bisa diperoleh keterangan atau informasi empiris yang detail dan akurat dari unit analisis penelitian (Bungin, 2010). Untuk mengetahui berbagai masalah dalam melakukan adopsi teknologi diperoleh data primer berdasarkan Focus Group Discussions (FGD). Sebagai sumber informasi pada diskusi ini digunakan beberapa pemilik industri. FGD dilakukan untuk mencari parameter penting pada setiap masalah yang berkaitan dengan adopsi teknologi.

\section{Analisis Data}

Parameter yang diperoleh melalui FGD dianalisa dengan menggunakan program Analytic Hierarchy Process (AHP) untuk mengetahui tingkat kepentingan masing-masing variabel berdasarkan nilainya. Setiap parameter pada masing-masing komponen mutu bahan baku diuji secara berpasangan. Pada pengujian ini dilihat parameter mana yang lebih penting. Tingkat kepentingan ditentukan berdasarkan skala kepentingannya. Analisis data struktur hirarki keputusan dan data hasil kuisioner (dengan menggunakan hasil komparasi berpasangan) dilakukan dengan mengunakan rumus matematik dalam proses hirarki analitik dan bantuan paket program AHP. Data hasil penelitian diolah untuk mengetahui konsistensi indeks dan konsistensi rasio matriks pendapat individunya. Jika pendapat individu tersebut tidak konsisten, maka dilakukan revisi pendapat.

\section{HASIL DAN PEMBAHASAN}

\section{A. Struktur Hierarki untuk Adopsi Teknologi}

Adopsi teknologi sangat diperlukan untu meningkatkan kualitas produksi. Hasil penelitian menunjukkan bahwa tujuan dari penerapan teknologi sangat mempengaruhi tingkkat adopsi. Para pemilik industri pangan skala kecil sangat membutuhkan teknologi yyang mampu meningkatkan dan nilai tambah pada produknya sehingga pada akhirnya teknologi tersebut akan mampu meningkatkan penjualannya.

Semua pihak yang terkait dengan proses adopsi teknologi harus dilibatkan secara aktif, khususnya para pemilik industri pangan lokal sebagai sasaran penerapan teknologi. Untuk itu perlu diupayakan agar materi pelatihan dan metoda pelaksanaannya yang sesuai dengan kondisi pemilik industri. Teknologi yang akan diterapkan harus mempunyai dampak positif terhadap kelangsungan industri. Dampak teknologi ditentukan oleh mutu produk yang dihasilkan, jumlah produksi, peningkatan keuntungan dan peningkatan pemasaran. Hierarki adopsi teknologi pada industri pangan lokal bisa dilihat pada Gambar 1 . 
Fokus

Adopsi Teknologi

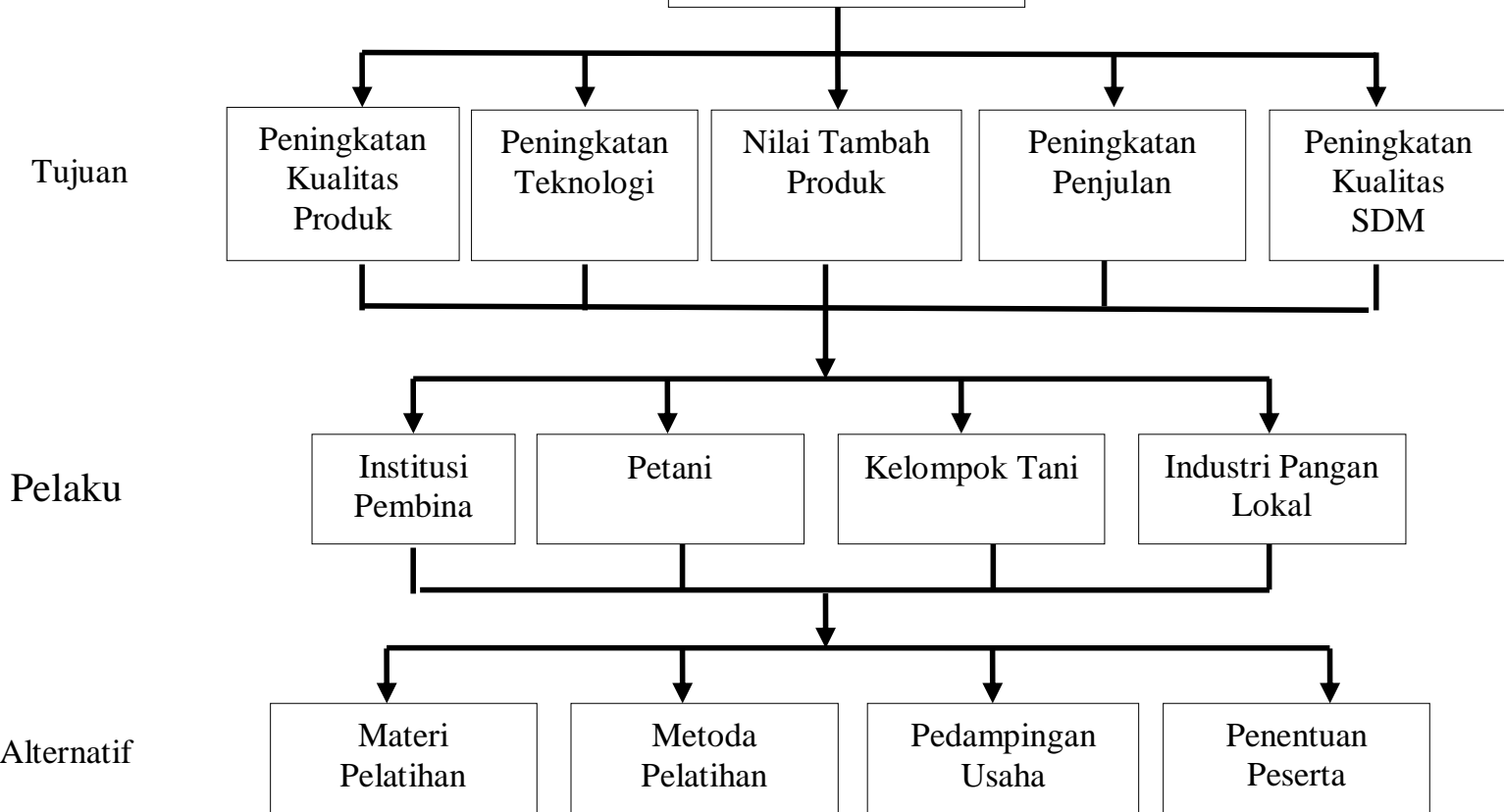

Gambar 1. Hierrarki Adopsi Teknologi Industri Pangan Lokal Skala Kecil di Sumatera Barat

\section{B. Tujuan Adopsi}

Pada hierarki adopsi teknologi diperoleh 4 level yaitu fokus, tujuan, pelaku dan alternatif. Pada level tujuan terdapat 5 komponen yang berdasarkan bobot tingkat kepentingannya diperoleh urutan sebagai berikut, peningkatan penjualan, peningkatan kualitas produk, peningkatan nilai tambah produk, peningkatan kualitas SDM dan peningkatan teknologi pada industri tersebut. Untuk lebih jelasnya dapat dilihat pada Gambar 2 berikut ini.

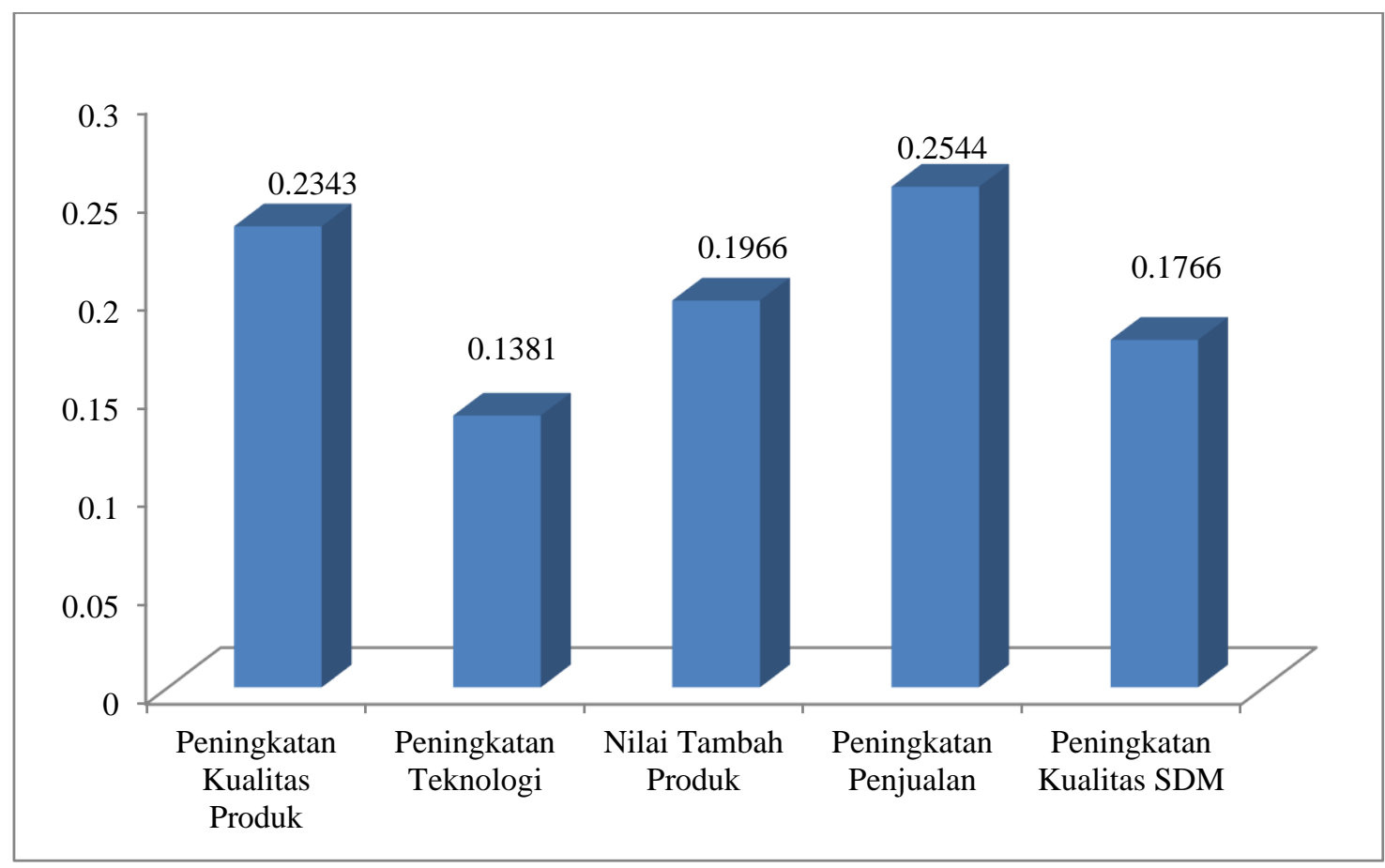

Gambar 2. Hasil Pembobotan Level Tujuan 
Untuk tercapainya tujuan dari adopsi teknologi harus diperhatikan berbagai hal yang terkait dengan karakter industri yang akan dikembangkan. Selain itu kondisi masyarakat sebagai pengguna teknologi juga harus diperhatikan. Begitu juga dengan faktor kelembagaan yang bertugas melakukan pembinaan terhadap perkembangan industri. Menurut Kuntariningsih (2014) kondisi sosial, ekonomi dan kelembagaan sangat mempengaruhi adopsi teknologi. Teknologi yang dilatihkan harus memperhatikan kearifan lokal dan penerapannya harus banyak memperhatikan partisipasi masyarakat.

\section{Pelaku yang Berperan}

Hierarki yang disusun memperlihatkan bahwa pelaku yang berperan pada adopsi teknologi adalah pemilik industri, kelompok tani, petani dan institusi pembina. Keempat pelaku ini mempunyai perbedaan tingkat kepentingan dan setelah pembobotan hasilnya dapat dilhat pada Gambar 3 berikut ini.

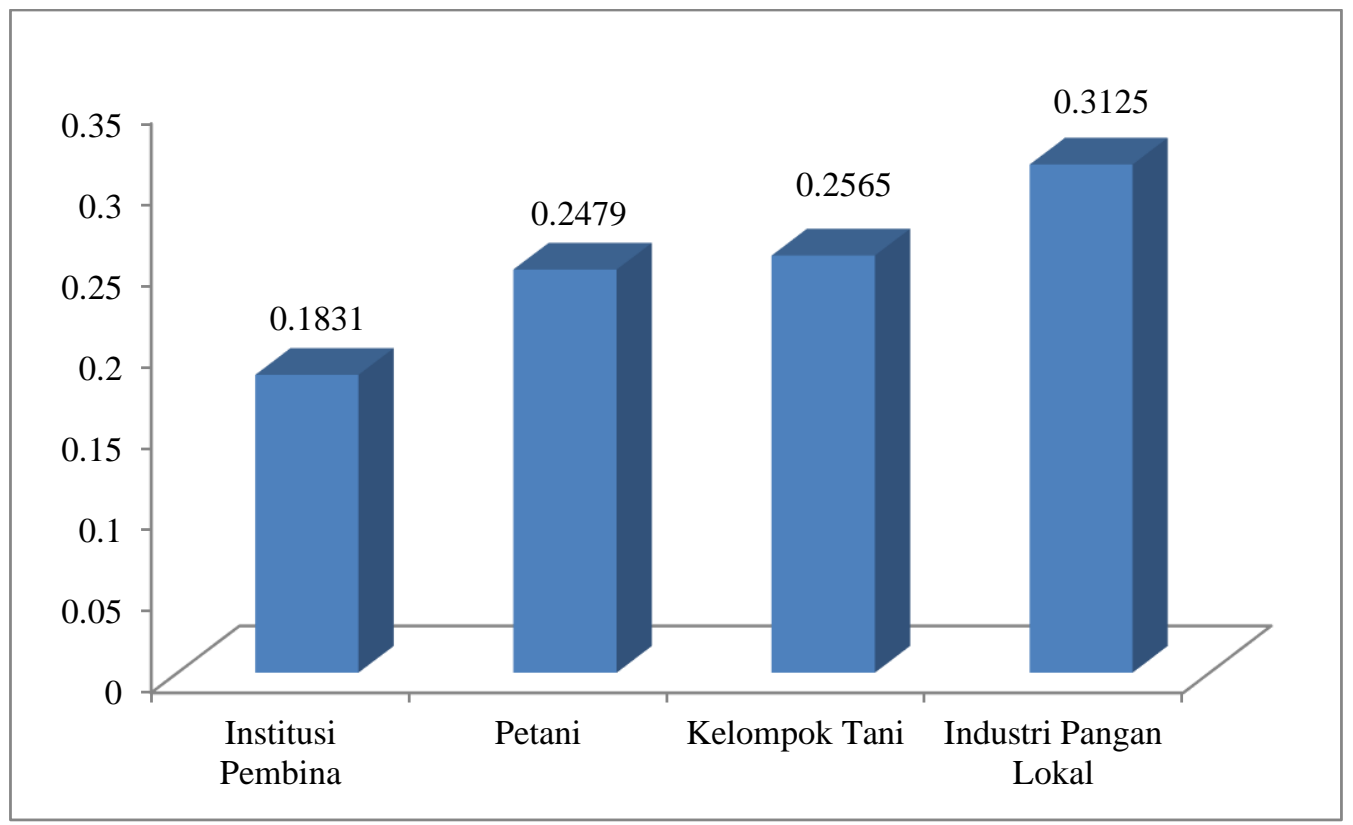

Gambar 3. Hasil Pembobotan Level Pelaku

Adopsi teknologi membutuhkan kesiapan pengguna untuk menerapkannya. Herman (2006) menyatakan bahwa adopsi teknologi dipengaruhi oleh sikap petani, tingkat pendapatan dan keberadaan pembina. Karena itu sangat diperlukan peran aktif pemerintah khususnya dalam pengadaan tenaga penyuluh yang mampu berfungsi sebagai pendamping usaha. Selain itu pemerintah juga diharapkan mampu mamfasilitasi pemodalan dengan bunga rendah. Adopsi teknologi diawali dengan perubahan pengetahuan dari tidak tahu menjadi tahu serta memahami tentang adanya teknologi yang mampu mengatasi masalah yang dihadapinya. Sikap petani sangat dipengaruhi oleh pengetahuannya, karakteristik petani dan karaktersitik teknologi yang akan diterapkan. Karena itu pemahaman terhadap karakter masyarakat sebagai pengguna teknologi harus menjadi kajian yang sangat penting. Karakteristik yang akan diterapkan harus disesuaikan dengan kondisi masyarakat setempat dan mempunyai kemudahan dalam penerapannya.

\section{Level Alternatif}

Pada level alternatif diperoleh beberapa hal penting yang berkaitan dengan pendampingan usaha, materi pelatihan, metode pelatihan dan penentuan peserta. Pembobotannya dapat dilihat pada Gambar 4.

Peran pemerintah sangat diperlukan untuk melakukan pendampingan dalam penerapan teknologi. Pendampingan sangat mempengaruhi tingkat kecenderungan penggunaan teknologi. Menurut Wulandari (2012) kecenderungan untuk menggunakan teknologi yang tinggi dipengaruhi oleh 
perilaku pengguna teknologi dalam penerapannya. Hal ini berkaitan dengan masih rendahnya fasilitas adopsi teknologi.

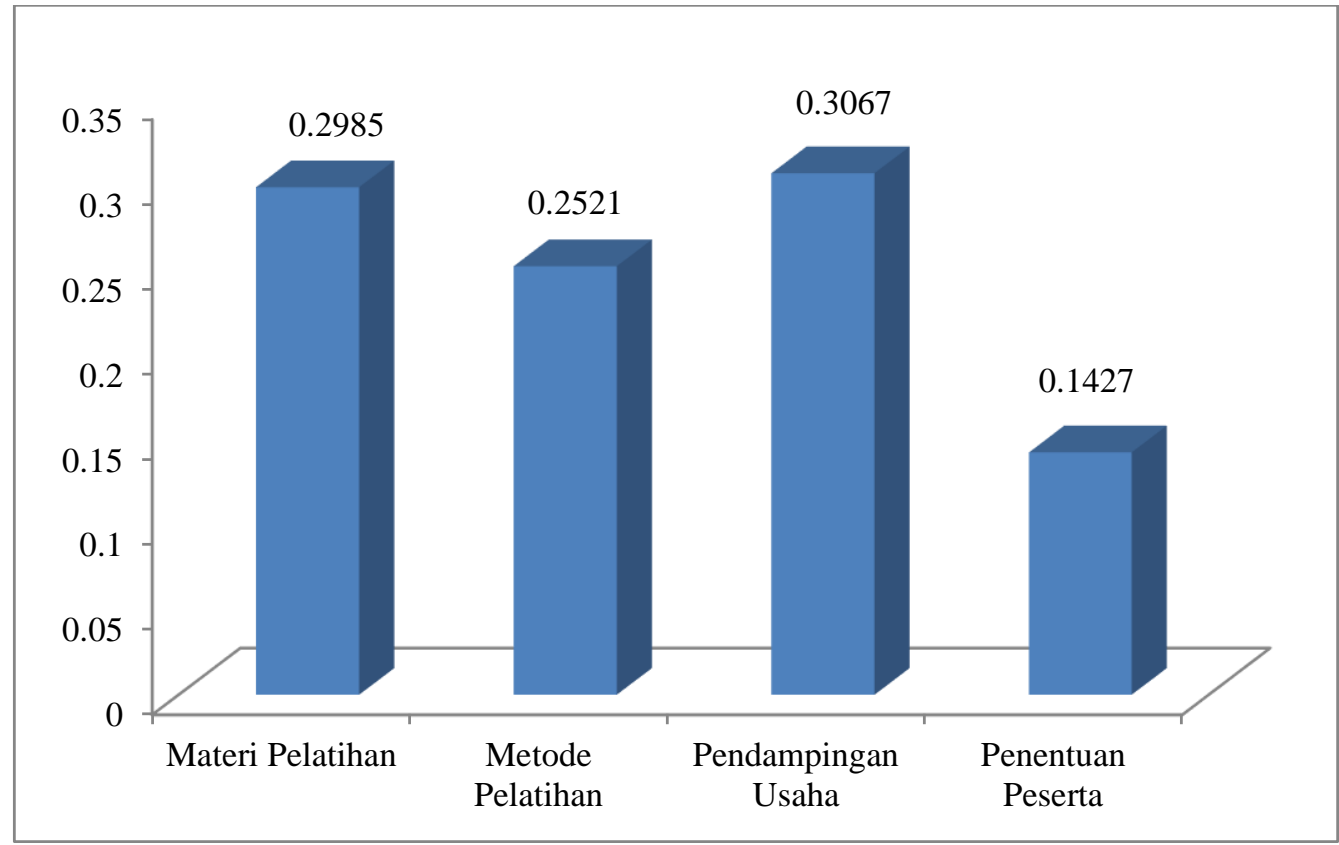

Gambar 4. Hasil Pembobotan Level Alternatif

Fasilitas yang diperlukan untuk adopsi teknologi sangat diperlukan karena sangat terkait dengan inovasi teknologi yang sudah merupakan salah satu kebutuhan dari pengembangan industri. Devanath (2008) menyatakan bahwa perkembangan dunia usaha termasuk usaha skala kecil sangat dipengaruhi oleh inovasi teknologi. Khusus usaha skala kecil sangat perlu mempunyai spesifikasi dalam berproduksi serta memilih teknologi yang tepat untuk dikembangkan dalam usahanya. Dengan mengadopsi teknologi yang tepat guna maka industri kecil akan mampu menghasilkan produk yang bermutu. Selain itu, teknologi tepat guna lebih mudah dalam operasional dan perawatan alatnya.

\section{KESIMPULAN}

Dari penelitian yang dilakukan dapat disimpulkan beberapa hal sebagai berikut:

1. Adopsi teknologi ditentukan oleh manfaat yang diperoleh seperti peningkatan penjualan, peningkatan kualitas produk, peningkatan nilai tambah produk, peningkatan kualitas SDM dan peningkatan teknologi pada industri tersebut.

2. Pelaku yang berperan pada adopsi teknologi adalah pemilik industri, kelompok tani, petani dan institusi pembina

3. Pelatihan yang dilakukan harus ditindak lanjuti dengan pendampingan usaha untuk memastikan terlaksananya adopsi teknologi dengan baik.

\section{DAFTAR PUSTAKA}

Bungin, B. 2010. Analisis Data Penelitian Kualitatif. PT Raja Grafindo Perkasa. Jakarta.

Devanath T. 2008. Role of Technological Innovations for Competitiveness and Entrepreneurship. Journal of Entrepreneurship India, Vol. 17, No. 2, 103-115 (2008).

Dinas Koperasi Perindustrian dan Perdagangan Sumatera Barat. 2014. Koperasi Industri dan Perdagangan Sumatera Barat Dalam Angka 2010. Dinas Perindustrian dan Perdagangan Sumatera Barat, Padang.

Dinas Pertanian Tanaman Pangan Propinsi Sumatera Barat. 2015. Profil Kelompok UP3HP di Sumatera Barat. Dinas Pertanian Tanaman Pangan Sumatera Barat, Padang. 
Herman, Hutagaol, M.P., Surjono, H., Sutjahjo, Rauf. A., Priyarsono, D.S. 2006. Analisis Faktorfaktor yah Mempengaruhi Adopsi Teknologi Pengendalian Hama Penggerek Buah Kakao. Pelita Perkebunan 22 (3), 222-236 Tahun 2006.

Kuntariningsih, A., Mariyono, J. 2014. Adopsi Teknologi Pertanian Untuk Pembangunan Pedesaan: Sebuah Kajian sosiologis. Agriekonomi Volume 3, Nomor 2 tahun 2014.

Taib, G. 2014. Evaluation in Component Technology Small Scale Food Industry Cluster in West Sumatera. International Journal on Advanced Science, Engineering and Information Technology. Volume 4 (2014) No 2.

Taib, G., Santosa., Masrul Djalal., Helmi. 2015. Characteristic of Small Scale Food Industry Cluster in West Sumatera. International Journal on Advanced Science, Engineering and Information Technology. Volume 5 (2015) No 2.

Wulandari, S., Eriyatno, Rusli, M.S., Kusmuljono, B.S. 2012. Model Proses Adopsi Teknologi di Agroindustri Lada dengan Fuzzy Inference System. Optimasi Sistem Industri. 